\title{
Therapeutic Potential of Stem Cells in Follicle Regeneration
}

\author{
Agnieszka Owczarczyk-Saczonek (D), ${ }^{1}$ Magdalena Krajewska-Włodarczyk (D), \\ Anna Kruszewska, ${ }^{1}$ Lukasz Banasiak, ${ }^{3}$ Waldemar Placek, ${ }^{1}$ Wojciech Maksymowicz, \\ and Joanna Wojtkiewicz iD $^{5,6,7}$ \\ ${ }^{1}$ Department of Dermatology, Sexually Transmitted Diseases and Clinical Immunology, University of Warmia and Mazury \\ in Olsztyn, Olsztyn, Poland \\ ${ }^{2}$ Department of Rheumatology, University of Warmia and Mazury in Olsztyn, Olsztyn, Poland \\ ${ }^{3}$ Department of Plastic, Reconstructive and Aesthetic Surgery, L. Rydygier Collegium Medicum in Bydgoszcz, Nicolaus Copernicus \\ University in Torun, Toruń, Poland \\ ${ }^{4}$ Department of Neurology and Neurosurgery, Faculty of Medical Sciences, University of Warmia and Mazury in Olsztyn, \\ Olsztyn, Poland \\ ${ }^{5}$ Foundation for Nerve Cell Regeneration, University of Warmia and Mazury in Olsztyn, Olsztyn, Poland \\ ${ }^{6}$ Department of Pathophysiology, Faculty of Medical Sciences, University of Warmia and Mazury in Olsztyn, Olsztyn, Poland \\ ${ }^{7}$ Laboratory for Regenerative Medicine, Faculty of Medical Sciences, University of Warmia and Mazury, Olsztyn, Poland
}

Correspondence should be addressed to Agnieszka Owczarczyk-Saczonek; aganek@wp.pl

Received 8 April 2018; Revised 24 June 2018; Accepted 22 July 2018; Published 5 August 2018

Academic Editor: Shibashish Giri

Copyright (c) 2018 Agnieszka Owczarczyk-Saczonek et al. This is an open access article distributed under the Creative Commons Attribution License, which permits unrestricted use, distribution, and reproduction in any medium, provided the original work is properly cited.

\begin{abstract}
Alopecia is caused by a variety of factors which affect the hair cycle and decrease stem cell activity and hair follicle regeneration capability. This process causes lower self-acceptance, which may result in depression and anxiety. However, an early onset of androgenic alopecia is associated with an increased incidence of the metabolic syndrome and an increased risk of the cardiac ischaemic disease. The ubiquity of alopecia provides an encouragement to seek new, more effective therapies aimed at hair follicle regeneration and neoregeneration. We know that stem cells can be used to regenerate hair in several therapeutic strategies: reversing the pathological mechanisms which contribute to hair loss, regeneration of complete hair follicles from their parts, and neogenesis of hair follicles from a stem cell culture with isolated cells or tissue engineering. Hair transplant has become a conventional treatment technique in androgenic alopecia (micrografts). Although an autologous transplant is regarded as the gold standard, its usability is limited, because of both a limited amount of material and a reduced viability of cells obtained in this way. The new therapeutic options are adipose-derived stem cells and stem cells from Wharton's jelly. They seem an ideal cell population for use in regenerative medicine because of the absence of immunogenic properties and their ease of obtainment, multipotential character, ease of differentiating into various cell lines, and considerable potential for angiogenesis. In this article, we presented advantages and limitations of using these types of cells in alopecia treatment.
\end{abstract}

\section{Introduction}

Hair loss is caused by a variety of factors: hereditary (trichodystrophy, androgenic alopecia), concomitant medical conditions, hormonal disorders (thyroid gland disorders, insulin resistance), autoimmune (patchy alopecia, systemic lupus erythematosus), nutritional disorders, environmental factors (medicines, UV radiation), psychological factors (stress, trichotillomania), and ageing. The damaging factors affect the hair cycle and decrease stem cell activity and hair follicle regeneration capability.

Alopecia is commonly regarded as a defect with apparently no significant health consequences. However, hair loss affects self-acceptance, which may result in depression and anxiety $[1,2]$. It is not only an aesthetic issue. An early onset of androgenic alopecia is associated with an increased 
incidence of the metabolic syndrome and an increased risk of the cardiac ischaemic disease [3]. The ubiquity of alopecia provides an encouragement to seek new, more effective therapies aimed at hair follicle regeneration and neoregeneration.

1.1. Stem Cells in the Hair Follicle. Hair follicles have a niche for mature stem cells-hair follicular stem cells (HFSCs) - a so-called "bulge" in the attachment region of arrector pili muscles, which contain epithelial and melanocyte stem cells. Moreover, HFSCs are also situated within the outer root sheath (ORS), within the region of the proximal end of the isthmus-this area is also known as the "bulge" [4]. HFSCs take part in the regeneration of epidermal cells and the structure of hair follicles and sebaceous glands [5] (Figure 1).

Stem cells of the "bulge" can remain in their niche where they self-regenerate, but they can also move down to the hair matrix region, where they become progenitor cells which then form an internal hair follicle and the hair stem [6]. The "bulge" region is not uniform, with two compartments distinguishable in it: the lower part, close to the hair matrix, which generates the internal hair follicle cell line, and the upper part, which self-regenerates, but which does not directly participate in the regeneration of the hair follicle $[7,8]$. Since the heterogeneity of the "bulge" also depends on its relationship with the basal membrane, two populations of CD34+ cells are distinguished. One of them, the so-called suprabasal SCs, contains lower levels of a6-intergin and has a lower proliferative potential $[6,9]$. The "isthmus" region is, apart from the "bulge," another one which also contains stem cells participating in the formation of interfollicular epidermis and sebaceous glands $[7,10]$.

Another type of stem cells within the hair follicle is dermal papilla cells (DPCs), probably originating from dermal condensation, which is the initial stage of the hair follicle development $[11,12]$. DPCs play an important role in induction and regulation of hair growth and the formation of new hair follicles $[11,13,14]$. Signals from DPCs activate stem cells in the "bulge" and germinal matrix cells in the late telogen/ early anagen phase $[11,15]$ by activating the $\mathrm{Wnt} / \beta$-catenin pathway $[11,16]$. Moreover, DPCs have potential for differentiation into lines of adipocytes and osteocytes [11, 17], and they can be transformed into pluripotential cells $[11,18]$.

Alopecia involves changes in two types of hair stem cells, both human hair follicle stem cells (HFSCs) and dermal papilla cells (DPCs) [19, 20]. They ensure conditions for proper hair regeneration [20]. In scarring alopecia (lupus erythematosus, lichen planus), inflammatory cell infiltration around the bulge results in an irreversible loss of HFSCs. Although the progenitor cells are damaged, HFSCs are preserved in patchy and androgenic alopecia. This is why this type of alopecia can be reversible [20].

Stem cells of the "bulge" are increasingly well characterised, especially in murine hair follicle, which facilitates their identification, although no universal marker has been found for them. One of them is cytokeratin 15 (CK15), which is why CK15+/integrin $\alpha 6+$ or CD34+/integrin $\alpha 6+$ cells have been identified as "bulge" cells [21]. Studies on murine hair follicles have also revealed expression of, inter alia,

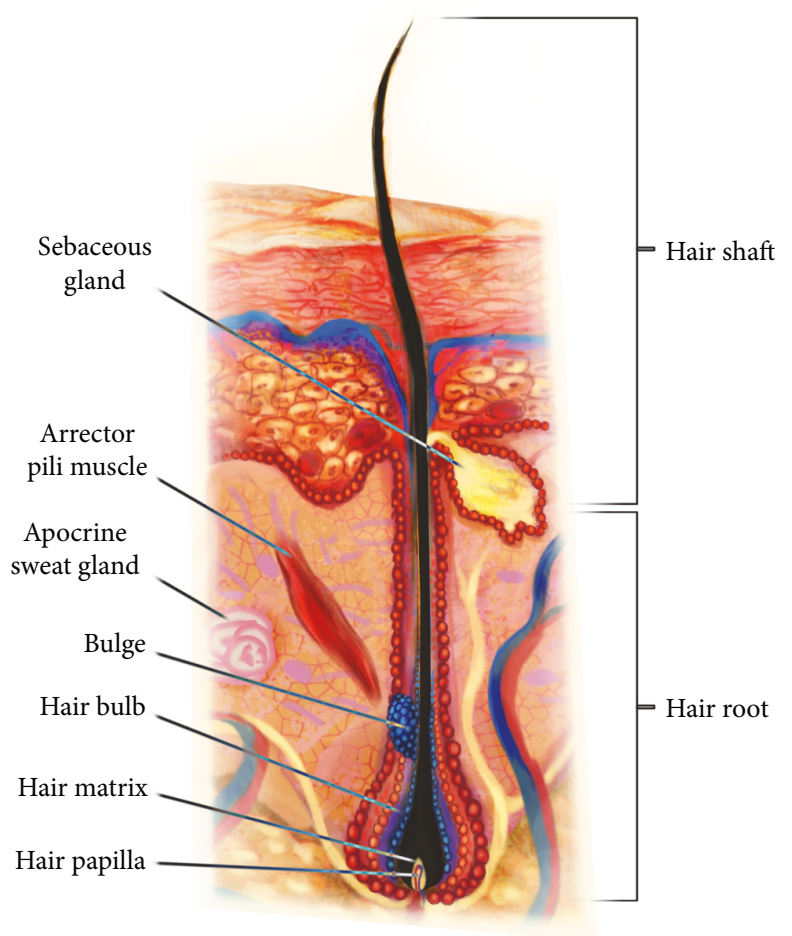

FIgURE 1: Hair follicle anatomy.

CK19 $[8,22]$ and numerous transcription factors, that is, Sox9, Lgr5, Gli1, Hopx, LHX2, Nfatc1, and Tcf3 [8, 25]. However, expression of certain markers depends on the hair cycle phase and on the precise location of the cells within the bulge $[7,8]$. Lgr5, a receptor involved in the Wnt signaling pathway, has been identified as an actual marker of the hair follicle stem cells [25]. Stem cells of the upper and lower parts of the bulge in the telogen hair follicle affect the expression of CD34 and only of the lower part of Lgr5. Cells participating in the formation of a new anagen hair express Lgr5, but not CD34 [26]. Cells of the upper part of the "bulge" present a higher expression Nfatc1, which is associated with a state of rest [6]. Expression of Lgr6 [7, 10] and Lrig1 [7, 27] has been observed within the "isthmus." Meanwhile, progenitor cells of the germinal matrix are derived from stem cells of the bulge but, unlike them, exhibit a high level of P-cadherin [8, 28].

Human hair follicle stem cells are less known than murine HFSCs. It seems that certain markers are common to both human and mouse HFSCs, that is, CD34 [4, 23], $\mathrm{K} 15$ [4, 19], K19 [4, 29], and CD200 [4, 19, 23]. The presence of other markers, i.e., Sox9 and LHX2, requires further studies [30]. Markers found only in human stem cell follicles belong to PHLDA1 $[4,24]$ and EpCAM/Ber-EP4, which is a useful marker of the telogen secondary hair germ $[4,28]$.

Dermal papilla cells present different markers, including those from hair follicle cells and dermal fibroblasts [11]. Alkaline phosphatase (ALP) is the most important for both human and murine HFs and is the most specific of the markers $[11,29,30]$; its high activity is a marker of DP cell differentiation $[11,31]$. Moreover, expression of $\alpha$-SMA 
$[11,17]$, laminin, and fibronectin [11] as well as CD133 [11, 32] has been observed in DPCs.

Marker expression changes in pathological states. Immunoreactivity of CK15 is decreased in people with patchy alopecia, and it is present in androgenic alopecia [21]. Hair follicles in the frontal parts of the scalp exhibit a deficit of CD34 in androgenic alopecia, and its expression is preserved in hair follicles of the occipital region [21]. Another marker CD200 of matrix cells is poorly expressed in patchy alopecia, which may be a sign of the disappearance of the immune privilege and can contribute to pathogenesis (reaction of autoreactive lymphocytes) [21,33].

Stem cells in the bulge remain in the resting phase for most of their lives, but they can be activated depending on the hair cycle phase. Most of the concepts regarding the course and regulation of the hair cycle have been created during research on mouse models. During the hair cycle in mice, in the anagen phase, stem cells in the bulge are divided three times on average and stay within the niche, whereas cells of the germinal matrix divide intensely and differentiate, forming the growing hair stem. During the catagen phase, cells of the germinal matrix undergo apoptosis; stem cells of the bulge migrate out of it to the external hair follicle, and subsequently, at the end of the catagen phase, they form a new bulge around the hair stem and a new germinal matrix under the bulge. Stem cells in the bulge remain in the state of rest during the telogen phase, and between the telogen and anagen phases, they self-regenerate or migrate, creating a pool of germinal matrix cells which subsequently proliferate to form the hair matrix [6]. The precedence has been shown for the derivative cells in the bulge, the so-called "SC" progenitor cells of the germinal matrix, in the expression of genes that affect stem cell activation, and precedence in proliferation during the regeneration cycle, even before the cells of the bulge $[8,15,34]$. The translation of the mouse hair cycle into the human hair cycle has some limitations due to the different lengths of anagen $[35,36]$, asynchrony of the human cycle $[35,37]$, or a different reaction to the influence of hormonal factors $[35,38]$. Currently, studies are conducted on human scalp skin xenografted into immunocompromised mice to establish the course of the hair cycle in vivo in humans [35].

The activity of stem cells in the bulge is controlled by the microenvironment that surrounds it, a so-called "niche." This includes daughter cells of stem cells of the bulge, which activate their self-regeneration during early and late anagen phases [39].

Stem cells are significantly affected by mesenchymal cells of the dermal papilla, which are in close contact with cells of the germinal matrix, separated only by the basal membrane [7]. They seem to be of key importance in the induction of hair growth and in signal transmission during its regeneration $[8,34]$. Experiments have shown that hair regeneration is not possible after laser ablation because the hair follicle cycle stops at the telogen phase without progressing to the anagen phase $[6,7,34,40]$. Injections of exosomes derived from DPCs to HFs have been found to accelerate the entry of anagen and catagen delay via the $\beta$-catenin and Shh pathways [41]. HFSCs are also affected by fibroblasts in the reticular and papillary layers of the dermis as well as of the subcutaneous tissue [7].

Within the niche there are also melanocyte stem cells, which are responsible for the formation of mature melanocytes that impart the colour to a growing hair. The survival and growth of MSCs depend on signals transmitted by hair follicle epithelial cells, for example, the TGF- $\beta$ or the Wnt pathway [7, 39]. The extracellular matrix is another component of the microenvironment. It directly affects stem cells by the formation of the basal membrane, with which stem cells are in contact modulated, for example, by integrins $[6,8]$.

Stem cells of hair follicles are also affected by the macroenvironment surrounding hair follicles, for example, adipose tissue. It seems to undergo similar changes to those of the hair follicle: the thickness of the adipose tissue increases during the anagen phase, and adipocytes proliferate intensively $[8,42]$. Adipocytes secrete BMP2 during the late catagen phase and early telogen phase, which favours the resting states in the niche, whereas secretion of BMP2 is reduced at the end of the telogen phase, which supports the activation of HFSCs $[8,42,43]$. Communication between adipose tissue and the epithelium runs in both directions. Mutations blocking the hair cycle have been found to inhibit adipogenesis, which suggests that epithelium cells send signals activating the proliferation of adipocytes $[6,42]$.

Nerve ends affect stem cells situated at the upper part of the Gli1+ bulge by a signal of the Shh pathway $[6,44]$. Therefore, denervation can reduce the effect of SCs in the "isthmus" on wound healing [6, 44]. However, it seems that nerves are not indispensable components of the niche, because denervation does not impair hair follicle regeneration, which may suggest that Gli+ cells receive Shh signal from other sources [7].

The hair follicle absorbs nutrients from the surrounding microvascular network, which is transformed during the hair cycle-angiogenesis is increased during the anagen phase $[6,45]$. Cells of the bulge and of the matrix can probably stimulate angiogenesis [6]. Delayed induction of angiogenesis, which accompanies impaired angiogenesis, has been observed in mice $[7,45]$. It has been suggested that stem cells in general prefer a low-oxygen environment, where they secrete marker of hypoxia $[6,46]$. The vascular network, especially that surrounding the "isthmus," containing venous vessels, can participate in maintaining the low-oxygen environment in the surrounding of the stem cell environment [6].

However, although the effect of the immune response has not been sufficiently elucidated, it is important that the role of maintaining the immune privilege of hair follicles, associated with decreased expression of MHC I molecules and with increased secretion of local immunosuppressors, should be maintained during the anagen phase $[6,47]$. The loss of this privilege and an immune attack on cells of the matrix and the bulge are associated with alopecia $[6,48]$. Dermal cells $\gamma \delta \mathrm{T}$ are known to modulate posttraumatic regeneration of hair follicles by secreting FGF9 [7, 49]. Macrophages, in turn, increase the level of Wnt7b and Wnt10a ligands during the telogen phase after undergoing apoptosis, whereby activating HFSCs $[6,7,50]$. Macrophages play an 


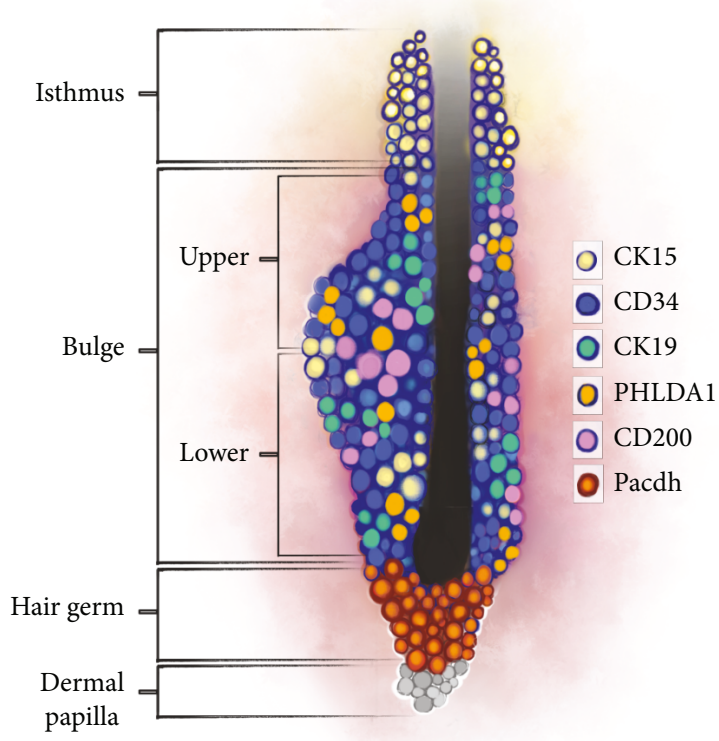

(a)

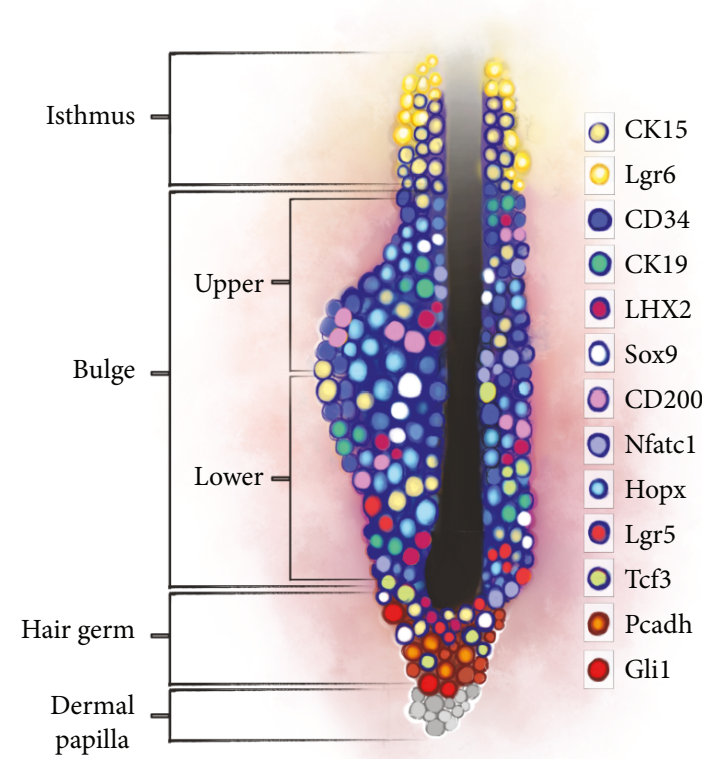

(b)

Figure 2: The markers of hair follicle: (a) in human, (b) in mouse.

important role in posttraumatic activation of HFSCs-arresting their recruitment into the wound delays hair growth, whereas transplantation of active macrophages is sufficient for induction of hair growth $[6,51]$. Also important is the role of Treg, which presents a high level of Jag 1 from the Notch family, which affects the effective regeneration of HF [52] (Figure 2 and Table 1).

1.2. Stem Cell Use in Hair Follicle Regeneration. Hair follicles are immunologically privileged places, like the brain, eyes, and testicles, and they are under the influence of the neuroendocrine-immune network [32]. In physiological conditions, this is affected by

(1) low expression or absence of the main MHC I antigens,

(2) the presence of malfunctional Langerhans cells,

(3) local expression of immunosuppressive substances (TGF- $\beta 1$ and $\alpha$-melanocytes MSH) $[32,48]$. Owing to this, they can be easily used in transplantation.

Multipotent stem cells can regenerate hair follicles with sebaceous glands in the skin. In the current state of knowledge, stem cells can be used to regenerate hair in several therapeutic strategies:

(1) Reversing the pathological mechanisms which contribute to hair loss (especially in androgenic alopecia)

(2) Regeneration of complete hair follicles from their parts (cells in the bulge can regenerate a whole hair)
(3) Neogenesis of hair follicles from a stem cell culture with isolated cells or tissue engineering $[5,53,54]$

1.3. Studies of Use of Autologous Stem Cell in Hair Follicle Regeneration. Hair transplant has become a conventional treatment technique in androgenic alopecia (micrografts, follicular unit transplantation (both FUT an FUE), and individual follicular group harvesting (IFGH)) [55]. Although an autologous transplant is regarded as the gold standard, its usability is limited, because of both a limited amount of material and a reduced viability of cells obtained in this way. Currently, methods are being developed which enhance the effectiveness of the use of autologous stem cells of the hair follicle.

Apart from cells of the "bulge," stem cells reside specifically in the HF mesenchyme and function to replenish the dermal papilla and connective tissue sheath. They are called self-renewing dermal stem cells (DSCs) $[56,57]$. When transplanted, DSCs integrate with mesenchymal cells and they act together with epithelial stem cells, participating in creating new hair follicles [56, 57]. In cultures, they form spherical, self-regenerating colonies. However, it is labour-consuming and ineffective. Therefore, methods have been developed for their simultaneous collection, isolation, and administration in vivo at acceptor sites with the use of the so-called stirred suspension bioreactors. They help to obtain cells of greater uniformity; increased cell density per volume; and control of the concentration of nutrients, metabolites, and growth factors $[56,58]$.

The findings of the study by Agabalyan et al. have confirmed that cells can retain their phenotype and an ability to form hair follicles even after five passages in bioreactors. 
TABLE 1: The markers of hair follicle and their role.

\begin{tabular}{|c|c|c|c|}
\hline Author & Signal & Researched object & Conclusions \\
\hline Telerman et al., 2017 [91] & Blimp1 & Transgenic mouse & $\begin{array}{c}\text { Ablation delayed HF morphogenesis, } \\
\text { and growth and prevented new HF formation } \\
\text { after wounding; role in promoting the dermal } \\
\text { papilla inductive signaling cascade that } \\
\text { initiates HF growth }\end{array}$ \\
\hline Kobielak et al., 2007 [92] & Bmprla & Transgenic mouse & $\begin{array}{l}\text { Ablation leads quiescent SCs to activate and } \\
\text { to proliferate, causing an expansion of the niche } \\
\text { and loss of slow-cycling cells; HFSCs are unable } \\
\text { to terminally differentiate into hair }\end{array}$ \\
\hline Lei et al., 2014 [93] & DKK1 & Transgenic mouse & $\begin{array}{l}\text { DKK reduce hair follicle enlargement and } \\
\text { decrease proliferation; injection of DKK1 } \\
\text { during early anagen significantly reduced } \\
\text { the width of prospective hairs }\end{array}$ \\
\hline Millar et al., 1999 [94] & Dvl2 & Transgenic mouse & $\begin{array}{l}\text { Overexpression in the outer root sheath } \\
\text { causes the short-hair phenotype }\end{array}$ \\
\hline Lin et al., 2015 [95] & $\begin{array}{l}\text { FGF1, FGF2, } \\
\text { FGF10 }\end{array}$ & Transgenic mouse & $\begin{array}{l}\text { Topical application of FGFs induced an } \\
\text { earlier anagen phase and prolonged the mature } \\
\text { anagen phase; FGFs promoted hair growth } \\
\text { by inducing the anagen phase in telogenic mice }\end{array}$ \\
\hline Kimura-Ueki et al., 2012 [96] & FGF18 & Transgenic mouse & $\begin{array}{l}\text { Ablation causes telogen to become very short, giving } \\
\text { rise to a strikingly rapid succession of hair cycles }\end{array}$ \\
\hline Higgins et al., 2014 [97] & FGF5 & $\begin{array}{l}\text { DNA from families } \\
\text { with long eyelashes }\end{array}$ & FGF5 is associated with long-hair phenotype \\
\hline Guo et al., 1993 [98] & FGF7 & Transgenic mouse & $\begin{array}{l}\text { Overexpression causes marked suppression of } \\
\text { hair follicle morphogenesis }\end{array}$ \\
\hline Petiot et al., 2003 [99] & Fgfr2 & Transgenic mouse & $\begin{array}{l}\text { Lack of Fgfr2 leads to a decreased number of HFs, } \\
\text { and follicles were developmentally retarded }\end{array}$ \\
\hline Öztürk et al., 2015 [100] & Gab1 & Transgenic mouse & $\begin{array}{l}\text { Lack of Gab1 caused HF not to enter } \\
\text { catagen; instead HFSCs lose quiescence }\end{array}$ \\
\hline Mill et al., 2003 [101] & Gli2 & Transgenic mouse & $\begin{array}{c}\text { Lack of Gli2 causes arrest in HF development } \\
\text { with reduced cell proliferation and Shh-responsive } \\
\text { gene expression, but normal epidermal } \\
\text { differentiation }\end{array}$ \\
\hline Estrach et al., 2006 [102] & Jagged-1 & Transgenic mouse & $\begin{array}{l}\text { Deletion of Jagged-1 results in inhibition of } \\
\text { the hair growth cycle and conversion of hair } \\
\text { follicles into cysts of cells undergoing } \\
\text { interfollicular epidermal differentiation }\end{array}$ \\
\hline Amalia Pasolli et al., 2014 [103] & LHX2 & Transgenic mouse & $\begin{array}{c}\text { Ablation of LHX2 results in cellular } \\
\text { disorganization and HFSC polarization } \\
\text { within the niche. LHX2 loss leads to a failure } \\
\text { to maintain HFSC quiescence and hair } \\
\text { anchoring and progressive transformation } \\
\text { of the niche into a sebaceous gland }\end{array}$ \\
\hline Öztürk et al., 2015 [100] & Mapk & Transgenic mouse & $\begin{array}{c}\text { Activation of Mapk signaling can restore } \\
\text { quiescence of the SCs }\end{array}$ \\
\hline Du et al., 2018 [104] & $\operatorname{miR}-214$ & $\begin{array}{l}\text { Human scalp skin } \\
\text { tissue; in vitro }\end{array}$ & $\begin{array}{l}\text { Downregulation of miR-214 promotes the } \\
\text { proliferation and differentiation of HFSCs; } \\
\text { overexpression of miR-214 led to decreased } \\
\text { expression of EZH2, } \beta \text {-catenin, and TCF } 4\end{array}$ \\
\hline Horsley et al., 2008 [105] & Nfatcl & Transgenic mouse & $\begin{array}{l}\text { Ablation causes stem cells to be activated } \\
\text { prematurely, resulting in precocious } \\
\text { follicular growth }\end{array}$ \\
\hline Krieger et al., 2018 [106] & $N F-\kappa B$ & Transgenic mouse & $\begin{array}{l}\text { Role in HF stem/progenitor cell activation } \\
\text { during anagen induction, involvement in hair } \\
\text { fiber morphogenesis during HF cycling }\end{array}$ \\
\hline
\end{tabular}


TABle 1: Continued.

\begin{tabular}{|c|c|c|c|}
\hline Author & Signal & Researched object & Conclusions \\
\hline Demehri and Kopan, 2009 [107] & Notch & Transgenic mouse & $\begin{array}{l}\text { Absence of Notch signaling leads bulge stem } \\
\text { cell descendents to retain their capacity to } \\
\text { execute the follicular differentiation program } \\
\text { but failing to maintain it owing to } \\
\text { their genetic deficiency }\end{array}$ \\
\hline Lin et al., 2011 [108] & Pofut1 & Transgenic mouse & $\begin{array}{l}\text { Disruption of Pofut1 in HF resulted in } \\
\text { aberrant telogen morphology, a decrease } \\
\text { of bulge SC markers; HF displayed a delay in } \\
\text { anagen reentry and dysregulation of proliferation } \\
\text { and apoptosis during the hair cycle transition }\end{array}$ \\
\hline Oro and Higgins, 2003 [109] & Ptch & Transgenic mouse & $\begin{array}{l}\text { Reduced Ptch is associated with tumor } \\
\text { formation during anagen }\end{array}$ \\
\hline Hoi et al., 2010 [110] & Runx1 & Transgenic mouse & $\begin{array}{c}\text { Role in promoting anagen onset and } \\
\text { HFSC proliferation }\end{array}$ \\
\hline St- Jacques et al., 1998 [111] & Shh & Transgenic mouse & $\begin{array}{l}\text { Shh signaling is not required for initiating } \\
\text { hair follicle development; however, it is } \\
\text { essential for controlling ingrowth and } \\
\text { morphogenesis of the hair follicle }\end{array}$ \\
\hline Kadaja et al., 2014 [112] & Sox 9 & Transgenic mouse & $\begin{array}{l}\text { Sox9-deficient bulge HFSCs begin to } \\
\text { differentiate into epidermal cells; as } \\
\text { HFSC numbers dwindle, outer root sheath } \\
\text { production is not sustained, and HF } \\
\text { down-growth arrests prematurely }\end{array}$ \\
\hline Foitzik et al., 2000 [113] & TGF- $\beta 1$ & Transgenic mouse & $\begin{array}{l}\text { Injection of TGF-betal induced } \\
\text { premature catagen development }\end{array}$ \\
\hline Foitzik et al., 1999 [114] & TGF- $\beta 2$ & Transgenic mouse & $\begin{array}{c}\text { Ablation causes delay of hair follicle } \\
\text { morphogenesis, with a } 50 \% \text { reduced } \\
\text { number of hair follicles }\end{array}$ \\
\hline Oshimori and Fuchs, 2012 [115] & TGF- $\beta$ RII & Transgenic mouse & $\begin{array}{l}\text { TGF- } \beta 2 \text { signaling antagonizes BMP } \\
\text { signaling in HFSCs with increased } \\
\text { telogen length }\end{array}$ \\
\hline Qiu et al., 2017 [116] & TPA & Transgenic mouse & $\begin{array}{l}\text { Refractory telogen hair follicles } \\
\text { entered anagen prematurely after } \\
\text { TPA treatment, with the enhanced } \\
\text { proliferation of CD34-positive hair } \\
\text { follicle stem cells }\end{array}$ \\
\hline Lei et al., 2014 [93] & Wnt10b & Transgenic mouse & $\begin{array}{l}\text { Prolonged overexpression increased } \\
\text { the size of regenerated hair follicles } \\
\text { and increased expression of CD34 } \\
\text { in the bulge }\end{array}$ \\
\hline Millar et al., 1999 [94] & Wnt3 & Transgenic mouse & $\begin{array}{l}\text { Overexpression causes a short-hair } \\
\text { phenotype and cyclical balding resulting } \\
\text { from hair shaft structural defects }\end{array}$ \\
\hline Dong et al., 2017 [117] & Wnt7a & Transgenic mouse & $\begin{array}{l}\text { Cultured human umbilical cord-MSCs } \\
\text { (UC-MSCs) overexpressing Wnt7a } \\
\text { can accelerate wound repair and induce } \\
\text { hair regeneration via cellular communication } \\
\text { in the wound microenvironment }\end{array}$ \\
\hline Kandyba and Kobielak, 2013 [118] & Wnt7b & Transgenic mouse & $\begin{array}{c}\text { Underexpression causes shorter anagen, } \\
\text { premature catagen onset with overall shorter } \\
\text { hair production, and diminished } \\
\text { HF differentiation marker expression }\end{array}$ \\
\hline Enshell-Seijffers et al., 2010 [119] & $\beta$-Catenin & Transgenic mouse & $\begin{array}{l}\text { Inactivation in DP of HF results in reduced } \\
\text { proliferation of the progenitors and their } \\
\text { immediate progeny that generate the HS } \\
\text { and premature catagen }\end{array}$ \\
\hline
\end{tabular}

HF: hair follicle; HS: hair shaft; DP: dermal papilla; SC: stem cell. 
Moreover, the productivity is five times higher compared to static cultures [56]. This has given rise to the possibility of using this method commercially in the treatment of alopecia.

Gentile et al. [5] demonstrated the application of an innovative Rigeneracons ${ }^{\circledR}$ bioreactor (certificate CE, class I) in order to provide autologous micrografts and their immediate use in clinical practice. They proved that cells isolated from the bulge region can improve the thickness of hair in patients affected by androgenic alopecia using a new method of isolating human mature stem cells obtained from a patient self-biopsy, without culturing. Enhanced hair thickness was achieved in 11 men (aged 38 to 61 years) with androgenic alopecia even at the stage of 3-5 in the NorwoodHamilton scale. After the biopsy and removal of unwanted remnants of fatty tissue, a medical device Rigeneracons (certificate CE, class I) was used to obtain cell suspension. The percentage of mesenchymal stem cells CD44+ from the dermal papilla was approx. $5 \%+0.7 \%$ and CD200+ from the bulge was approx. $2.6 \%+0.3 \%$. After 23 weeks of therapy, after the last administration of stem cells, the average number of hairs and their thicknesses increased by $29 \% \pm 5 \%$ compared to the baseline for the hair thickness in the treated area and by less than $1 \%$ of hair thickness increase in the placebo area [5].

Furthermore, Nilforoushzadeh et al. [59] evaluated the regeneration potential of cultured mature dermal papilla to induce the growth of a hair follicle injected to the skin of bare mice. Initially, dermal papilla cells in the culture were observed to multiply with expression of CD200, and these fusiform cells tended to form colonies after three to five days. Subsequently, after two weeks, they acquired a passaging capability and they formed an extracellular matrix after the third passaging. Histopathological examination in mice which received $1.2 \times 10^{6}$ of cells of dermal papilla revealed structures that transformed into hair follicles at sites of injection in the dermis [59].

Ibrahim et al. used autologous bone marrow mononuclear cells (BMMC) (including stem cells) to treat refractory patchy alopecia and androgenic alopecia, and the therapeutic effects were compared to the group treated with autologous stem cells of hair follicles. Cells were administered in a single application ( 1 millilitre in a density of $100,000 \mathrm{cell} / \mathrm{ml}$ was injected, using a 26-gauge needle, intradermally at per centimetre square of the treated site), and a significant improvement was observed in all patient groups under treatment [21]. Interestingly, the effect of stem cells was similar despite the fact that they had been obtained from two different sources. The effect of intradermal injection of BMMC may result from the diversity of the cell mixture: progenitor, hematopoietic stem cells, various types of inflammatory cells, and mesenchymal stem cells. BMMC can stimulate hair growth as a consequence of the ability to differentiate into various cell types, the ability to secrete bioactive molecules which stimulate angiogenesis (VEGF) and antiinflammatory molecules with an immunomodulatory and antiapoptotic effect [21].

1.4. Studies of the Use of Adipose-Derived Stem Cells. ADSCs (adipose-derived stem cells) seem an ideal cell population for use in regenerative medicine because of the absence of immunogenic properties, their ease of obtainment, multipotential character, ease of differentiating into various cell lines, and considerable potential for angiogenesis. ADSCs have been shown to originate from mural cells located in the perivascular niche, vascular smooth muscle cells and pericytes, both involved in the formation of normal vasculature and are responsive to VEGF [60]. Naturally, hair follicles surrounded by subcutaneous adipose cells and by dermis form an interfollicular dermal macroenvironment, which is important in maintaining the proper growth of bulge and follicle cells $[11,61,62]$. ADSCs are indispensable in the activation of epidermal stem cells, which they do by secreting growth factors. The vascular endothelial growth factor (VEGF) regulates hair growth and the size of the hair follicle size by stimulation of angiogenesis. The hepatocyte growth factor (HGF) is involved in the duration of the hair cycle phases. The platelet-derived growth factor induces and maintains the anagen phase, and the insulin-like growth factor I (IGF-I) controls the hair growth cycle and hair cell differentiation [11, 63-67]. Another direction of their action is the stimulation of angiogenesis and an improvement of the blood supply to dermal papilla cells. They also have immunomodulatory and immunosuppressive properties through the direct interaction between cells and secretion of prostaglandin E2 (PGE2), leukaemiainhibiting factor (LIF), and kynurenine $[11,62]$.

The paracrine activity of ADSCs is highly complex, and the factors secreted by stem cells have both a direct and an indirect effect on hair follicles. TB4 contributes to the activation of stem cells in a hair follicle, increasing their migration into the follicle and differentiation. SDF-1 acts through an increase in expression of EGR-1; it also increases the cell tropism towards the follicle and increases angiogenesis. The action of MCP-1 is less obvious; despite being an inflammatory factor, it has a proven tissue regenerative effect; also, a significant role of the microenvironment in the effect of paracrine factors in promoting the growth of the hair follicle has been emphasised [68]. Huang et al., in a study on rats, found that an addition of ADSCs to a culture of dermal papilla cells or core cells, the inner and outer sheath, enhances their viability [64]. A significant increase in the regenerative potential was recorded in a study by Huang et al., in which ADSCs were enriched with LL-37, which is an antibacterial peptide occurring naturally in wounds [64]. That study showed a significant increase in the local regenerative factors (endothelial growth factor, thymosin beta-4, monocyte chemoattractant protein-1, and stromal cell-derived factor-1). A significant promotion of the growth of hair follicles, in both in vitro and in vivo animal models, was observed [60,69-71].

Physiologically, adipose tissue surrounding hair follicles plays an important role in extending the anagen phase. Adipocytes progenitor cells have been observed to multiply during the transition from the telogen to the anagen phase, around the hair follicle $[61,64]$. The thickness of the subcutaneous layer increases significantly during the intense hair growth phase (anagen) compared to their amount in the resting phase (telogen) [11,59]. ADSCs stimulate hair follicle cells through peroxisome proliferator-activated receptors, 
whose three isoforms have been found on their surface (PPAR $\alpha, \operatorname{PPAR} \gamma$, and PPAR $\delta$ ) [64]. Meanwhile, mature adipocytes have a negative effect on hair follicle cell proliferation and on proliferation of fibroblasts surrounding the hair follicle in simultaneous culture systems [11, 72].

Interestingly, a change in adipocyte cell line properties can cause skin and hair disorders. Lipid metabolism disorders can cause defects in the skin structure and functions. Over-expression of human apolipoprotein C1 (APOC1) with hyperlipidemia in transgenic mice causes hair growth disorders correlated with the level of expression of human APOC1 gene in the skin $[11,73]$.

Hypoxia, which is not toxic to mesenchymal cells, also increases the production of growth factors for ADSCs: vascular endothelial growth factor (VEGF), platelet-derived growth factor (PDGF), hepatocyte growth factor (HGF), and insulin-like growth factor II (IGF-II) [74, 75]. The effect of hypoxia on ADSCs was examined in a study conducted by Park et al. [74]. ADSCs passaged four times with $\mathrm{CO}_{2}$ subsequently administered subcutaneously to mice to observe induction of the anagen phase and proliferation of human follicular cells of the dermal papilla and keratinocytes. Hypoxia resulted in increased secretion of insulin-like growth factor-binding protein-1 and protein-2 (IGFBP), macrophage colony stimulating factor (M-CSF), M-CSF receptor, PDGF receptor- $\beta$, and VEGF, whereas secretion of the epidermal growth factor was smaller [74].

Unfortunately, two-dimensional (2D) cultures of dermal papilla cells lose their hair formation capability in culture, which is why they require maintaining their spheroidal forms (3D) $[76,77]$. It is a challenge to develop methods that mimic in vivo conditions, which both maintain the $3 \mathrm{D}$ structure of cells and contain a special medium which imitates a natural niche rich in growth factors $[56,75]$.

Currently, there are no known tissue regeneration protocols applied for hair transplant with the use of ADSCs. Zanzoterra et al. [78] examined the capabilities of autologous cell suspension in the Rigenera system, which were obtained by mechanical fragmentation of subcutaneous and adipose tissue from the occipital area. The cell suspension was applied in the hair transplant area, thereby increasing the amount of growth factors. Microdamage has been observed to heal more quickly and to transplant hair to grow continuously even two months after the procedure, with the telogen phase shortened [78].

An ADSC-conditioned medium (ADSC-CM) was used in patients with alopecia (both male and female) in a study by Fukuoka and Suga [63]. A commercial product containing a protein solution with ADSCs was used (AAPE, Prostemics, Seoul, Korea) with various growth factors (hepatocyte growth factor, fibroblast growth factor I, granulocyte colony-stimulating factor, granulocyte macrophage-colonystimulating factor, IL-6, VEGF, and TGF). The preparation $\left(0.02 \mathrm{ml} / \mathrm{cm}^{2}\right.$ of the solution) was administered intradermally every 3 to 5 weeks (4-6 sessions), and hair growth was monitored with trichograms. A significant improvement in hair thickness was achieved in patients of both sexes [63].

Shin et al. [71] used ADSC and conditioned media of ADSCs (ADSC-CM) in a retrospective, observational study in 27 women with a female pattern hair loss (FPHL). The application of ADSC-CM showed efficacy in treating FPHL after 12 weeks of therapy with increased hair density and thickness without severe adverse reactions [71]. Won et al. [79] also showed that the application of ADSC-CM enhanced proliferation of cultured human dermal papilla cells (DPCs) by up to $130 \%$ [79].

Other studies have confirmed that enriching adipose tissue with a stromal vesicular fraction (SVF) supports adipocyte viability and yields better outcomes for a hair transplant procedure when they are present in grafts $[62,80]$. Lipoaspirate obtained from abdominal fat (system Puregraft LLC, Solana Beach, CA, USA) was administered to the scalp at $1.0 \mathrm{ml} / \mathrm{cm}^{2}$ in a Perez-Meza study. The amount of hair was found to increase by $23 \%$ after six months of the follow-up period [80].

\subsection{Studies on Using Stem Cells from Wharton's Jelly}

1.5.1. The Advantage of Stem Cells from Wharton's Jelly Compared to Other Mesenchymal Cells. Wharton's jelly has become a preferential source of stem cells due to its ready availability from a large pool of donors, noninvasive and painless acquisition, no risk to the donor, no ethical limitations, weak immunogenic potential, and high multipotential differentiation capability [81, 82]. Moreover, exposure to infectious agents occurs rarely, which guarantees safety to the donor [83].

Additionally, the decellularized Wharton's jelly matrix (DWJM) (fresh jelly was subjected to two cycles of osmotic shock, alternately with a hypertonic solution of $\mathrm{NaCl}$, mannitol, $\mathrm{MgCl}_{2}$, and $\mathrm{KCl}$ with the osmolarity of approx. $1.275 \mathrm{mOsm} / 1$, and centrifuged at $5000 \mathrm{rpm}$ at $4^{\circ} \mathrm{C}$ against a hypotonic solution of $0.005 \%$ Triton X-100) can provide a natural scaffolding for stem cells as a biocompatible matrix, which supports their viability, initiating aggregation of mesenchymal cells. DWJM contains TGF- $\beta$, collagen I, fibronectin, and tenascin, which may be responsible for condensation of added WJMSC in some areas of the DWJM. Hence, DWJM is a natural biocompatible 3D matrix which ensures adhesion, penetration, growth, and proliferation of cells-both in vitro and in vivo. To conclude, this paper presents DWJM as a new and natural 3D scaffolding which can be used in tissue engineering and regenerative medicine [84].

1.5.2. Neogenesis of Hair Follicles with Stem Cell Culture on Media and Grafting Them into the Skin: In Vitro Regeneration. In 2013, two researchers, demonstrated that it is possible to obtain cells with an expression of cytokeratin 19 and hair-like structures from WJMSC in in vitro conditions. Cytokeratin 19 (CK19) is a marker of bulge stem cells which determines the self-regeneration potential of modified skin $[85,86]$.

The Korean team of Yoo et al. [87-89] examined the effect of hWJSC on the acceleration of wound healing processes along with formation of hair follicles and other skin appendages. Enriched aggregates of hWJSC cells can form new hair follicles. The addition of growth factors to the culture medium is required: hepatocyte growth factor (HGF) 


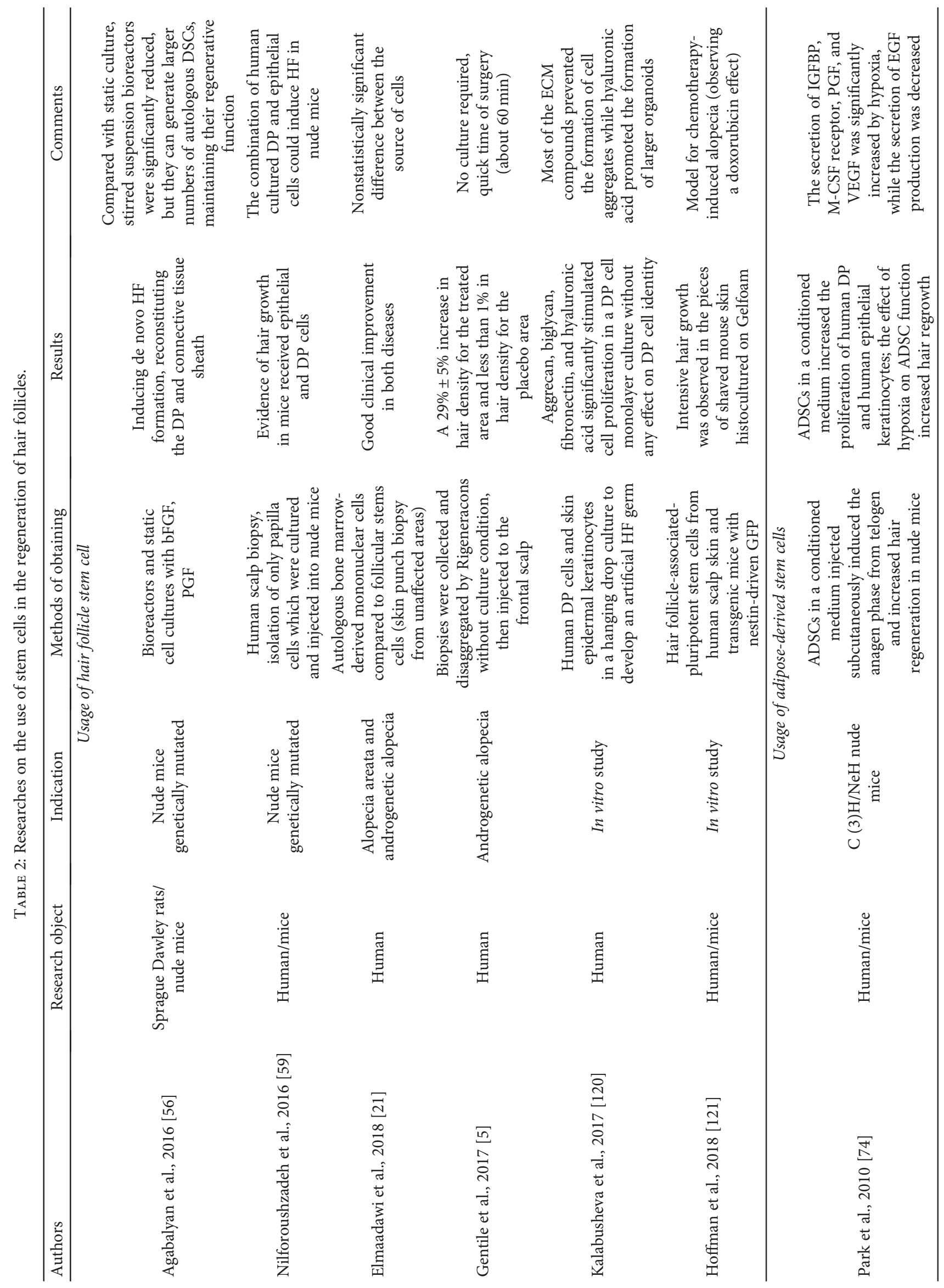




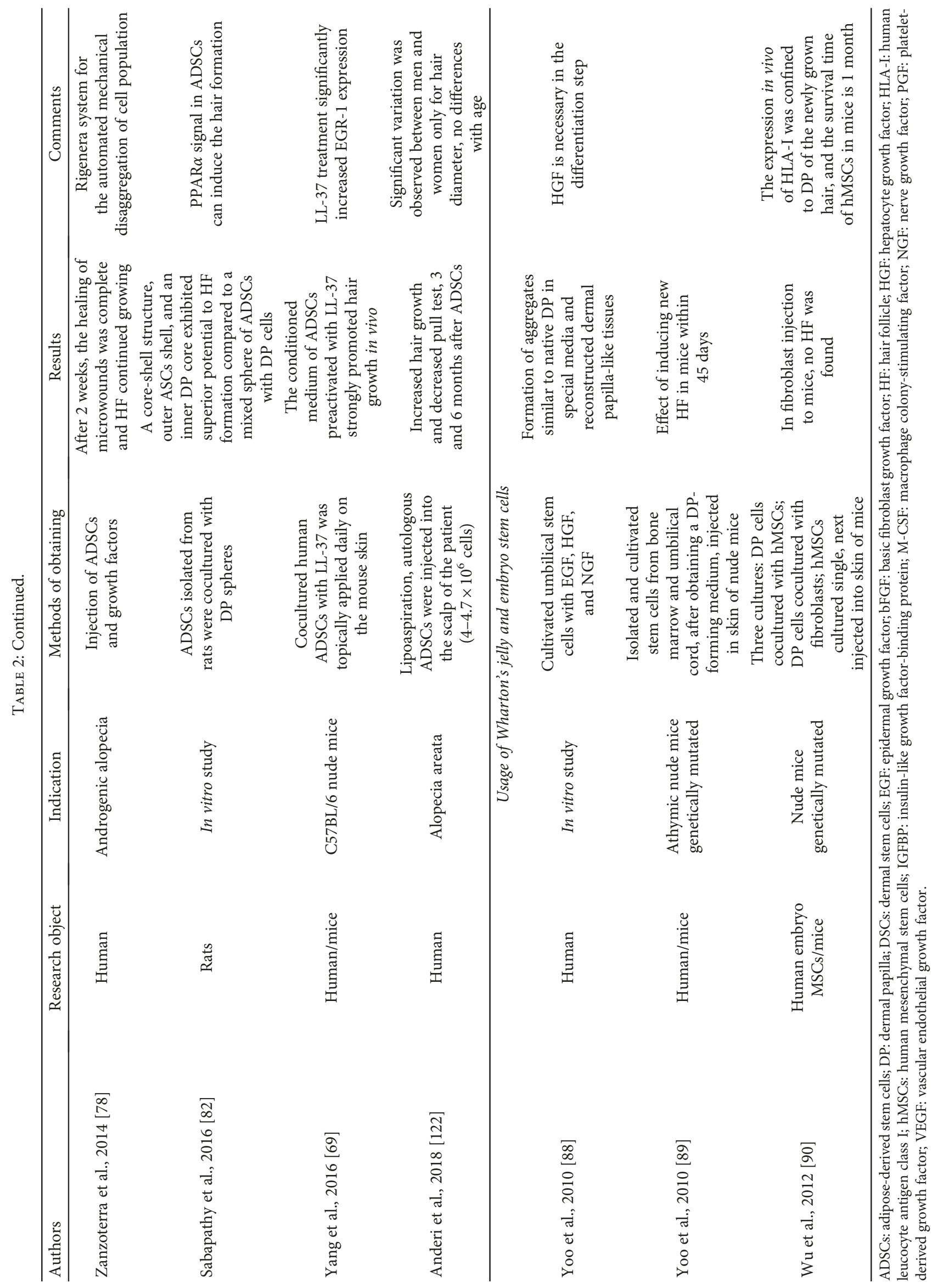




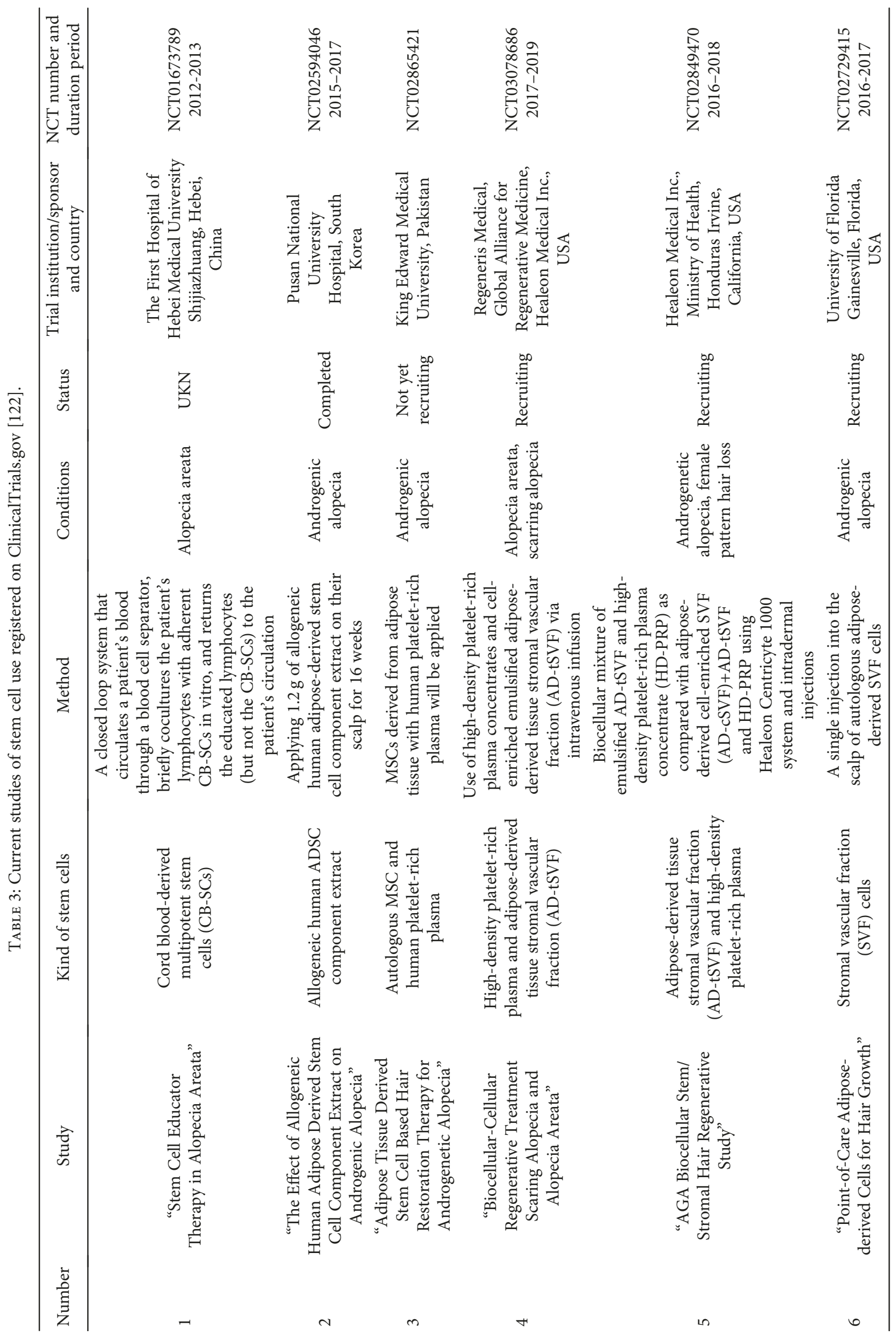


stimulates growth of hair follicles in vivo and in vitro; basic fibroblast growth factor (bFGF) stimulates growth of dermal papilla cells in vivo; and vesicular endothelial growth factor (VEGF) stimulates growth of hair follicles and hair root in vivo. The hepatocyte growth factor (HGF) must be used at the stage of differentiation of the dermal papilla in culture, which is relatively expensive [87-89].

Moreover, Yoo et al. [88] compared effects of culturing bone marrow and umbilical cord stem cells to the spontaneous formation of dermal papilla-like tissues (DPLT). Isolated cells of the hair outer sheath were used for incubation: DPLT were recovered from $25 \mathrm{~T}$ cell culturing plates and mixed with 1106 cells of hair sheath in $50 \mathrm{ml}$ of physiological saline and injected into mice skin. The mice were examined after six weeks. Subsequently, the clinical effects of hair follicle formation in originally bare mice following their implantation in the skin were compared. No differences between the methods were observed [88].

Wu et al. (a Chinese study) [90] demonstrated the potential for differentiation of hMSC (from human embryos) to dermal papilla cells in cocultures of hMSC using dermal papilla cells previously obtained from patients. Expression of versican, CD133, SCF (stem cell factor), ET-1 (endothelin-1), and bFGF (fibroblast growth factor) was observed during the process of differentiation [90].

1.5.3. Neogenesis of Hair Follicles from Isolated Cells (Stem Cells from Wharton's Jelly): In Vivo Regeneration. Intensive studies are being conducted on the commercial use of hWJSC in alopecia treatment at the University of Kansas Innovation and Collaboration, Kansas, USA (Dr. Omar Aljitawi) (no literature data) (Tables 2 and 3).

\section{Conclusion}

Maintaining a pool of stem cells is necessary for tissue homeostasis and damage repair. Their divisions are not frequent in mature organisms, and most of them are in a dormant state. Therefore, it is important to understand the mechanisms of their activation, which will allow for the use of multipotent cells in regenerative medicine [33]. Their use is additionally complicated by the fact that expression of receptors on different growth factors and the effect of the microenvironment may vary. Moreover, not all target points in stem cell therapy have been identified. It requires further studies aimed not only at the use of stem cells and their various fractions and compositions with adjuvants but also at broadening of knowledge on the physiology and cytophysiology of the hair follicle [35].

\section{Conflicts of Interest}

The authors declare that they have no conflicts of interest.

\section{References}

[1] A. Adil and M. Godwin, "The effectiveness of treatments for androgenetic alopecia: a systematic review and meta-analysis," Journal of the American Academy of Dermatology, vol. 77, no. 1, pp. 136-141.e5, 2017.
[2] W. C. Cranwell and R. Sinclair, "Familial frontal fibrosing alopecia treated with dutasteride, minoxidil and artificial hair transplantation," Australasian Journal of Dermatology, vol. 58, no. 3, pp. e94-e96, 2017.

[3] S. M. Lesko, L. Rosenberg, and S. Shapiro, "A case-control study of baldness in relation to myocardial infarction in men," Journal of the American Medical Association, vol. 269, no. 8, pp. 998-1003, 1993.

[4] T. S. Purba, I. S. Haslam, E. Poblet et al., "Human epithelial hair follicle stem cells and their progeny: current state of knowledge, the widening gap in translational research and future challenges," BioEssays, vol. 36, no. 5, pp. 513-525, 2014.

[5] P. Gentile, M. G. Scioli, A. Bielli, A. Orlandi, and V. Cervelli, "Stem cells from human hair follicles: first mechanical isolation for immediate autologous clinical use in androgenetic alopecia and hair loss," Stem Cell Investigation, vol. 4, no. 7, p. 58, 2017.

[6] K. Turksen, Tissue Specific Stem Cell Niche, Springer, 2015.

[7] G. Guasch, "The epithelial stem cell niche in skin," in Biology and engineering of stem cell niches, A. Vishwakarma and J. Karp, Eds., pp. 127-143, Elsevier Inc., 2017.

[8] P. Rompolas and V. Greco, "Stem cell dynamics in the hair follicle niche," Seminars in Cell and Developmental Biology, vol. 25-26, pp. 34-42, 2014.

[9] C. Blanpain, W. E. Lowry, A. Geoghegan, L. Polak, and E. Fuchs, "Self-renewal, multipotency, and the existence of two cell populations within an epithelial stem cell niche," Cell, vol. 118, no. 5, pp. 635-648, 2004.

[10] H. J. Snippert, A. Haegebarth, M. Kasper et al., "Lgr6 marks stem cells in the hair follicle that generate all cell lineages of the skin," Science, vol. 327, no. 5971, pp. 1385-1389, 2010.

[11] P. Zhang, R. E. Kling, S. K. Ravuri et al., "A review of adipocyte lineage cells and dermal papilla cells in hair follicle regeneration," Journal of Tissue Engineering, vol. 5, 2014.

[12] R. R. Driskell, C. Clavel, M. Rendl, and F. M. Watt, "Hair follicle dermal papilla cells at a glance," Journal of Cell Science, vol. 124, no. 8, pp. 1179-1182, 2011.

[13] M. Rendl, L. Polak, and E. Fuchs, "BMP signaling in dermal papilla cells is required for their hair follicle-inductive properties," Genes \& Development, vol. 22, no. 4, pp. 543-557, 2008.

[14] T. Matsuzaki and K. Yoshizato, "Role of hair papilla cells on induction and regeneration processes of hair follicles," Wound Repair and Regeneration, vol. 6, no. 6, pp. 524-530, 1998.

[15] V. Greco, T. Chen, M. Rendl et al., "A two-step mechanism for stem cell activation during hair regeneration," Cell Stem Cell, vol. 4, no. 2, pp. 155-169, 2009.

[16] P. Rabbani, M. Takeo, W. Chou et al., "Coordinated activation of Wnt in epithelial and melanocyte stem cells initiates pigmented hair regeneration," Cell, vol. 145, no. 6, pp. 941955, 2011.

[17] C. A. B. Jahoda, C. J. Whitehouse, A. J. Reynolds, and N. Hole, "Hair follicle dermal cells differentiate into adipogenic and osteogenic lineages," Experimental Dermatology, vol. 12, no. 6, pp. 849-859, 2003.

[18] S. Y. Tsai, C. Clavel, S. Kim et al., "Oct4 and Klf4 reprogram dermal papilla cells into induced pluripotent stem cells," Stem Cells, vol. 28, no. 2, pp. 221-228, 2010. 
[19] M. Ohyama, A. Terunuma, C. L. Tock et al., "Characterization and isolation of stem cell-enriched human hair follicle bulge cells," Journal of Clinical Investigation, vol. 116, no. 1, pp. 249-260, 2006.

[20] P. Mohammadi, K. K. Youssef, S. Abbasalizadeh, H. Baharvand, and N. Aghdami, "Human hair reconstruction: close, but yet so far," Stem Cells and Development, vol. 25, no. 23, pp. 1767-1779, 2016.

[21] I. H. Elmaadawi, B. M. Mohamed, Z. A. S. Ibrahim et al., "Stem cell therapy as a novel therapeutic intervention for resistant cases of alopecia areata and androgenetic alopecia," Journal of Dermatological Treatment, vol. 29, no. 5, pp. 431440, 2018.

[22] A. L. Means, Y. Xu, A. Zhao, K. C. Ray, and G. Gu, "CK19 CreERT knockin mouse line allows for conditional DNA recombination in epithelial cells in multiple endodermal organs," Genesis, vol. 46, no. 6, pp. 318-323, 2008.

[23] K. Inoue, N. Aoi, T. Sato et al., "Differential expression of stem-cell-associated markers in human hair follicle epithelial cells," Laboratory Investigation, vol. 89, no. 8, pp. 844-856, 2009.

[24] K. Sellheyer and D. Krahl, "PHLDA1 (TDAG51) is a follicular stem cell marker and differentiates between morphoeic basal cell carcinoma and desmoplastic trichoepithelioma," British Journal of Dermatology, vol. 164, no. 1, pp. 141-147, 2011.

[25] V. Jaks, N. Barker, M. Kasper et al., "Lgr5 marks cycling, yet long-lived, hair follicle stem cells," Nature Genetics, vol. 40, no. 11, pp. 1291-1299, 2008.

[26] J. D. Hoeck, B. Biehs, A. V. Kurtova et al., "Stem cell plasticity enables hair regeneration following Lgr5+ cell loss," Nature Cell Biology, vol. 19, no. 6, pp. 666-676, 2017.

[27] K. B. Jensen, C. A. Collins, E. Nascimento et al., "Lrig1 expression defines a distinct multipotent stem cell population in mammalian epidermis," Cell Stem Cell, vol. 4, no. 5, pp. 427-439, 2009.

[28] M. Ozawa, S. Aiba, M. Kurosawa, and H. Tagami, “Ber-EP4 antigen is a marker for a cell population related to the secondary hair germ," Experimental Dermatology, vol. 13, no. 7, pp. 401-405, 2004.

[29] K. J. McElwee, S. Kissling, E. Wenzel, A. Huth, and R. Hoffmann, "Cultured peribulbar dermal sheath cells can induce hair follicle development and contribute to the dermal sheath and dermal papilla," Journal of Investigative Dermatology, vol. 121, no. 6, pp. 1267-1275, 2003.

[30] S.-H. Lee, J. Yoon, S. H. Shin et al., "Valproic acid induces hair regeneration in murine model and activates alkaline phosphatase activity in human dermal papilla cells," PLoS One, vol. 7, no. 4, article e34152, 2012.

[31] M. Rendl, L. Lewis, and E. Fuchs, "Molecular dissection of mesenchymal-epithelial interactions in the hair follicle," PLoS Biology, vol. 3, no. 11, p. e331, 2005.

[32] Y. Ito, T. S. Hamazaki, K. Ohnuma, K. Tamaki, M. Asashima, and $\mathrm{H}$. Okochi, "Isolation of murine hair-inducing cells using the cell surface marker prominin-1/CD133," Journal of Investigative Dermatology, vol. 127, no. 5, pp. 1052-1060, 2007.

[33] J. Li, T. X. Jiang, and C. M. Chuong, "Many paths to alopecia via compromised regeneration of hair follicle stem cells," Journal of Investigative Dermatology, vol. 133, no. 6, pp. 1450-1452, 2013.
[34] P. Rompolas, K. R. Mesa, and V. Greco, "Spatial organization within a niche as a determinant of stem-cell fate," Nature, vol. 502, no. 7472, pp. 513-518, 2013.

[35] J. W. Oh, J. Kloepper, E. A. Langan et al., "A guide to studying human hair follicle cycling in vivo," Journal of Investigative Dermatology, vol. 136, no. 1, pp. 34-44, 2016.

[36] L. A. Garza, Y. Liu, Z. Yang et al., "Prostaglandin D2 inhibits hair growth and is elevated in bald scalp of men with androgenetic alopecia," Science Translational Medicine, vol. 4, no. 126, article 126ra34, 2012.

[37] J. Halloy, B. A. Bernard, G. Loussouarn, and A. Goldbeter, "Modeling the dynamics of human hair cycles by a follicular automaton," Proceedings of the National Academy of Sciences of the United States of America, vol. 97, no. 15, pp. 8328-8333, 2000.

[38] M. Nakamura, M. R. Schneider, R. Schmidt-Ullrich, and R. Paus, "Mutant laboratory mice with abnormalities in hair follicle morphogenesis, cycling, and/or structure: an update," Journal of Dermatological Science, vol. 69, no. 1, pp. 6-29, 2013.

[39] S. Tanimura, Y. Tadokoro, K. Inomata et al., "Hair follicle stem cells provide a functional niche for melanocyte stem cells," Cell Stem Cell, vol. 8, no. 2, pp. 177-187, 2011.

[40] E. R. Deschene, P. Myung, P. Rompolas et al., " $\beta$-catenin activation regulates tissue growth non-cell autonomously in the hair stem cell niche," Science, vol. 343, no. 6177, pp. $1353-$ 1356, 2014.

[41] L. Zhou, H. Wang, J. Jing, L. Yu, X. Wu, and Z. Lu, "Regulation of hair follicle development by exosomes derived from dermal papilla cells," Biochemical and Biophysical Research Communications, vol. 500, no. 2, pp. 325-332, 2018.

[42] M. V. Plikus, J. A. Mayer, D. de la Cruz et al., "Cyclic dermal BMP signalling regulates stem cell activation during hair regeneration," Nature, vol. 451, no. 7176, pp. 340-344, 2008.

[43] R. Yi, "Concise review: mechanisms of quiescent hair follicle stem cell regulation," Stem Cells, vol. 35 , no. 12, pp. $2323-$ 2330, 2017.

[44] I. Brownell, E. Guevara, C. B. Bai, C. A. Loomis, and A. L. Joyner, "Nerve-derived sonic hedgehog defines a niche for hair follicle stem cells capable of becoming epidermal stem cells," Cell Stem Cell, vol. 8, no. 5, pp. 552-565, 2011.

[45] L. Mecklenburg, D. J. Tobin, S. Müller-Röver et al., "Active hair growth (anagen) is associated with angiogenesis," Journal of Investigative Dermatology, vol. 114, no. 5, pp. 909916, 2000.

[46] A. Mohyeldin, T. Garzón-Muvdi, and A. Quiñones-Hinojosa, "Oxygen in stem cell biology: a critical component of the stem cell niche," Cell Stem Cell, vol. 7, no. 2, pp. 150-161, 2010.

[47] T. Christoph, S. Müller-Röver, H. Audring et al., "The human hair follicle immune system: cellular composition and immune privilege," British Journal of Dermatology, vol. 142, no. 5, pp. 862-873, 2000.

[48] R. PAUS, B. NICKOLOFF, and T. ITO, "A 'hairy' privilege," Trends in Immunology, vol. 26, no. 1, pp. 32-40, 2005.

[49] D. Gay, O. Kwon, Z. Zhang et al., "Fgf9 from dermal $\gamma \delta \mathrm{T}$ cells induces hair follicle neogenesis after wounding," Nature Medicine, vol. 19, no. 7, pp. 916-923, 2013.

[50] D. Castellana, R. Paus, and M. Perez-Moreno, "Macrophages contribute to the cyclic activation of adult hair 
follicle stem cells," PLoS Biology, vol. 12, no. 12, article e1002002, 2014.

[51] N. Osaka, T. Takahashi, S. Murakami et al., "ASK1-dependent recruitment and activation of macrophages induce hair growth in skin wounds," The Journal of Cell Biology, vol. 176, no. 7, pp. 903-909, 2007.

[52] N. Ali, B. Zirak, R. S. Rodriguez et al., "Regulatory T cells in skin facilitate epithelial stem cell differentiation," Cell, vol. 169, no. 6, pp. 1119-1129.e11, 2017.

[53] K. Asakawa, K. E. Toyoshima, N. Ishibashi et al., "Hair organ regeneration via the bioengineered hair follicular unit transplantation," Scientific Reports, vol. 2, no. 1, p. 424, 2012.

[54] M. E. Balañá, H. E. Charreau, and G. J. Leirós, "Epidermal stem cells and skin tissue engineering in hair follicle regeneration," World Journal of Stem Cells, vol. 7, no. 4, pp. 711-727, 2015.

[55] J. P. Cole, "An analysis of follicular punches, mechanics, and dynamics in follicular unit extraction," Facial Plastic Surgery Clinics of North America, vol. 21, no. 3, pp. 437-447, 2013.

[56] N. A. Agabalyan, B. S. Borys, H. D. Sparks et al., "Enhanced expansion and sustained inductive function of skin-derived precursor cells in computer-controlled stirred suspension bioreactors," Stem Cells Translational Medicine, vol. 6, no. 2, pp. 434-443, 2017.

[57] J. Biernaskie, M. Paris, O. Morozova et al., "SKPs derive from hair follicle precursors and exhibit properties of adult dermal stem cells," Cell Stem Cell, vol. 5, no. 6, pp. 610-623, 2009.

[58] C. A. V. Rodrigues, T. G. Fernandes, M. M. Diogo, C. L. da Silva, and J. M. S. Cabral, "Stem cell cultivation in bioreactors," Biotechnology Advances, vol. 29, no. 6, pp. 815-829, 2011.

[59] M. Nilforoushzadeh, E. Rahimi Jameh, F. Jaffary et al., "Hair follicle generation by injections of adult human follicular epithelial and dermal papilla cells into nude mice," Cell Journal, vol. 19, no. 2, pp. 259-268, 2017.

[60] M. Gaur, M. Dobke, and V. Lunyak, "Mesenchymal stem cells from adipose tissue in clinical applications for dermatological indications and skin aging," International Journal of Molecular Sciences, vol. 18, no. 1, 2017.

[61] E. Festa, J. Fretz, R. Berry et al., "Adipocyte lineage cells contribute to the skin stem cell niche to drive hair cycling," Cell, vol. 146, no. 5, pp. 761-771, 2011.

[62] M. Zhu, Z. Zhou, Y. Chen et al., "Supplementation of fat grafts with adipose-derived regenerative cells improves long-term graft retention," Annals of Plastic Surgery, vol. 64, no. 2, pp. 222-228, 2010.

[63] H. Fukuoka and H. Suga, "Hair regeneration treatment using adipose-derived stem cell conditioned medium: follow-up with trichograms," Eplasty, vol. 15, 2015.

[64] C.-F. Huang, Y.-J. Chang, Y.-Y. Hsueh et al., "Assembling composite dermal papilla spheres with adipose-derived stem cells to enhance hair follicle induction," Science Reports, vol. 6 , no. 1, 2016.

[65] I. Hwang, K.-A. Choi, H.-S. Park et al., "Neural stem cells restore hair growth through activation of the hair follicle niche," Cell Transplantation, vol. 25, no. 8, pp. 1439-1451, 2016.

[66] A. Rezza, R. Sennett, M. Tanguy, C. Clavel, and M. Rendl, "PDGF signalling in the dermis and in dermal condensates is dispensable for hair follicle induction and formation," Experimental Dermatology, vol. 24, no. 6, pp. 468-470, 2015.
[67] K. Yano, L. F. Brown, and M. Detmar, "Control of hair growth and follicle size by VEGF-mediated angiogenesis," The Journal of Clinical Investigation, vol. 107, no. 4, pp. 409-417, 2001.

[68] S. Wood, V. Jayaraman, E. J. Huelsmann et al., "Pro-inflammatory chemokine CCL2 (MCP-1) promotes healing in diabetic wounds by restoring the macrophage response," PLoS One, vol. 9, no. 3, article e91574, 2014.

[69] Y. Yang, H. Choi, M. Seon, D. Cho, and S. I. Bang, "LL-37 stimulates the functions of adipose-derived stromal/stem cells via early growth response 1 and the MAPK pathway," Stem Cell Research \& Therapy, vol. 7, no. 1, p. 58, 2016.

[70] H. Shin, H. H. Ryu, O. Kwon, B. S. Park, and S. J. Jo, "Clinical use of conditioned media of adipose tissue-derived stem cells in female pattern hair loss: a retrospective case series study," International Journal of Dermatology, vol. 54, no. 6, pp. 730735, 2015.

[71] H. Shin, C. H. Won, W. K. Chung, and B. S. Park, "Up-todate clinical trials of hair regeneration using conditioned media of adipose-derived stem cells in male and female pattern hair loss," Current Stem Cell Research \& Therapy, vol. 12, no. 7, pp. 524-530, 2017.

[72] N. Misago, S. Toda, H. Sugihara, H. Kohda, and Y. Narisawa, "Proliferation and differentiation of organoid hair follicle cells co-cultured with fat cells in collagen gel matrix culture," British Journal of Dermatology, vol. 139, no. 1, pp. 40-48, 1998.

[73] M. C. Jong, M. J. Gijbels, V. E. Dahlmans et al., "Hyperlipidemia and cutaneous abnormalities in transgenic mice overexpressing human apolipoprotein C1," Journal of Clinical Investigation, vol. 101, no. 1, pp. 145-152, 1998.

[74] B.-S. Park, W.-S. Kim, J.-S. Choi et al., "Hair growth stimulated by conditioned medium of adipose-derived stem cells is enhanced by hypoxia: evidence of increased growth factor secretion," BioMed Research International, vol. 31, no. 1, 34 pages, 2010.

[75] S. Ramdasi and S. K. Tiwari, "Human mesenchymal stem cell-derived conditioned media for hair regeneration applications," Journal of Stem Cells, vol. 11, no. 4, pp. 201-211, 2016.

[76] B. M. Kang, M. H. Kwack, M. K. Kim, J. C. Kim, and Y. K. Sung, "Sphere formation increases the ability of cultured human dermal papilla cells to induce hair follicles from mouse epidermal cells in a reconstitution assay," Journal of Investigative Dermatology, vol. 132, no. 1, pp. 237-239, 2012.

[77] C. H. Seo, M. H. Kwack, S. H. Lee, M. K. Kim, J. C. Kim, and Y. K. Sung, "Poor capability of 3D-cultured adipose-derived stem cells to induce hair follicles in contrast to 3D-cultured dermal papilla cells," Annals of Dermatology, vol. 28, no. 5, pp. 662-665, 2016.

[78] F. Zanzottera, E. Lavezzari, L. Trovato, A. Icardi, and A. Graziano, "Adipose derived stem cells and growth factors applied on hair transplantation. Follow-up of clinical outcome," Journal of Cosmetics, Dermatological Sciences and Applications, vol. 4, no. 4, pp. 268-274, 2014.

[79] C. H. Won, H. G. Yoo, O. S. Kwon et al., "Hair growth promoting effects of adipose tissue-derived stem cells," Journal of Dermatological Science, vol. 57, no. 2, pp. 134-137, 2010.

[80] D. Perez-Meza, C. Ziering, M. Sforza, G. Krishnan, E. Ball, and E. Daniels, "Hair follicle growth by stromal vascular fraction-enhanced adipose transplantation in baldness," 
Stem Cells and Cloning: Advances and Applications, vol. 10, pp. 1-10, 2017.

[81] S. M. Richardson, G. Kalamegam, P. N. Pushparaj et al., "Mesenchymal stem cells in regenerative medicine: Focus on articular cartilage and intervertebral disc regeneration," Methods, vol. 99, pp. 69-80, 2016.

[82] V. Sabapathy, B. Sundaram, S. VM, P. Mankuzhy, and S. Kumar, "Human Wharton's jelly mesenchymal stem cells plasticity augments scar-free skin wound healing with hair growth," PLoS One, vol. 9, no. 4, article e93726, 2014.

[83] Q. Wang, Q. Yang, Z. Wang et al., "Comparative analysis of human mesenchymal stem cells from fetal-bone marrow, adipose tissue, and Warton's jelly as sources of cell immunomodulatory therapy," Human Vaccines \& Immunotherapeutics, vol. 12, no. 1, pp. 85-96, 2015.

[84] S. Jadalannagari, G. Converse, C. McFall et al., "Decellularized Wharton's jelly from human umbilical cord as a novel $3 \mathrm{D}$ scaffolding material for tissue engineering applications," PLoS One, vol. 12, no. 2, article e0172098, 2017.

[85] A. G. Abdou, M. A. Wahed, A. A.-W. Saleh, D. El Sakka, M. A. W. Gaber, and W. Shehata, "Stem cell markers (cytokeratin 17 and cytokeratin 19) in scarring and nonscarring alopecia," Journal of Cutaneous and Aesthetic Surgery, vol. 9, no. 3, pp. 165-171, 2016.

[86] O. S. Aljitawi, Y. Xiao, D. Zhang et al., "Generating CK19positive cells with hair-like structures from Wharton's jelly mesenchymal stromal cells," Stem Cells and Development, vol. 22, no. 1, pp. 18-26, 2013.

[87] B. Y. Yoo, Y. H. Shin, H. H. Yoon, Y. K. Seo, and J. K. Park, "Hair follicular cell/organ culture in tissue engineering and regenerative medicine," Biochemical Engineering Journal, vol. 48, no. 3, pp. 323-331, 2010.

[88] B. Y. Yoo, Y. H. Shin, H. H. Yoon, Y. K. Seo, K. Y. Song, and J. K. Park, "Application of mesenchymal stem cells derived from bone marrow and umbilical cord in human hair multiplication," Journal of Dermatological Science, vol. 60, no. 2, pp. 74-83, 2010.

[89] B. Y. Yoo, Y. H. Shin, H. H. Yoon, Y. K. Seo, K. Y. Song, and J. K. Park, "Optimization of the reconstruction of dermal papilla like tissues employing umbilical cord mesenchymal stem cells," Biotechnology and Bioprocess Engineering, vol. 15, no. 1, pp. 182-190, 2010.

[90] M. Wu, Q. Sun, X. Guo, and H. Liu, "hMSCs possess the potential to differentiate into DP cells in vivo and in vitro," Cell Biology International Reports, vol. 19, no. 2, pp. 37-43, 2012.

[91] S. B. Telerman, E. Rognoni, I. Sequeira et al., "Dermal Blimp1 acts downstream of epidermal TGF $\beta$ and $\mathrm{Wnt} / \beta$-catenin to regulate hair follicle formation and growth," Journal of Investigative Dermatology, vol. 137, no. 11, pp. 2270-2281, 2017.

[92] K. Kobielak, N. Stokes, J. de la Cruz, L. Polak, and E. Fuchs, "Loss of a quiescent niche but not follicle stem cells in the absence of bone morphogenetic protein signaling," Proceedings of the National Academy of Sciences of the United States of America, vol. 104, no. 24, pp. 1006310068, 2007.

[93] M. Lei, H. Guo, W. Qiu et al., "Modulating hair follicle size with Wnt10b/DKK1 during hair regeneration," Experimental Dermatology, vol. 23, no. 6, pp. 407-413, 2014.

[94] S. E. Millar, K. Willert, P. C. Salinas et al., "WNT signaling in the control of hair growth and structure," Developmental Biology, vol. 207, no. 1, pp. 133-149, 1999.
[95] W. H. Lin, L. J. Xiang, H. X. Shi et al., "Fibroblast growth factors stimulate hair growth through $\beta$-catenin and Shh expression in C57BL/6 mice," BioMed Research International, vol. 2015, Article ID 730139, 9 pages, 2015.

[96] M. Kimura-Ueki, Y. Oda, J. Oki et al., "Hair cycle resting phase is regulated by cyclic epithelial FGF18 signaling," Journal of Investigative Dermatology, vol. 132, no. 5, pp. 13381345, 2012.

[97] C. A. Higgins, L. Petukhova, S. Harel et al., "FGF5 is a crucial regulator of hair length in humans," Proceedings of the National Academy of Sciences, vol. 111, no. 29, pp. 1064810653, 2014.

[98] L. Guo, Q. C. Yu, and E. Fuchs, "Targeting expression of keratinocyte growth factor to keratinocytes elicits striking changes in epithelial differentiation in trans-genic mice," EMBO Journal, vol. 12, no. 3, pp. 973-986, 1993.

[99] A. Petiot, F. J. Conti, R. Grose, J. M. Revest, K. M. HodivalaDilke, and C. Dickson, "A crucial role for Fgfr2-IIIb signalling in epidermal development and hair follicle patterning," Development, vol. 130, no. 22, pp. 5493-5501, 2003.

[100] Ö. Akilli Öztürk, H. Pakula, J. Chmielowiec et al., "Gab1 and Mapk signaling are essential in the hair cycle and hair follicle stem cell quiescence," Cell Reports, vol. 13, no. 3, pp. 561-572, 2015.

[101] P. Mill, R. Mo, H. Fu et al., "Sonic hedgehog-dependent activation of Gli2 is essential for embryonic hair follicle development," Genes \& Development, vol. 17, no. 2, pp. 282-294, 2003.

[102] S. Estrach, C. A. Ambler, C. L. Lo Celso, K. Hozumi, and F. M. Watt, "Jagged 1 is a $\beta$-catenin target gene required for ectopic hair follicle formation in adult epidermis," Development, vol. 133, no. 22, pp. 4427-4438, 2006.

[103] H. Amalia Pasolli, A. R. Folgueras, and E. Fuchs, "Architectural niche organization by LHX2 is linked to hair follicle stem cell function," Microscopy and Microanalysis, vol. 20, no. S3, pp. 1382-1383, 2014.

[104] K.-T. Du, J.-Q. Deng, X.-G. He, Z.-p. Liu, C. Peng, and M.-S. Zhang, "MiR-214 regulates the human hair follicle stem cell proliferation and differentiation by targeting $\mathrm{EZH} 2$ and $\mathrm{Wnt} / \beta$-catenin signaling way in vitro," Tissue Engineering and Regenerative Medicine, vol. 15, no. 3, pp. 341-350, 2018.

[105] V. Horsley, A. O. Aliprantis, L. Polak, L. H. Glimcher, and E. Fuchs, "NFATc1 balances quiescence and proliferation of skin stem cells," Cell, vol. 132, no. 2, pp. 299-310, 2008.

[106] K. Krieger, S. E. Millar, N. Mikuda et al., "NF- $\kappa$ B participates in mouse hair cycle control and plays distinct roles in the various pelage hair follicle types," Journal of Investigative Dermatology, vol. 138, no. 2, pp. 256-264, 2018.

[107] S. Demehri and R. Kopan, "Notch signaling in bulge stem cells is not required for selection of hair follicle fate," Development, vol. 136, no. 6, pp. 891-896, 2009.

[108] H.-Y. Lin, C.-H. Kao, K. M.-C. Lin, V. Kaartinen, and L.-T. Yang, "Notch signaling regulates late-stage epidermal differentiation and maintains postnatal hair cycle homeostasis," PLoS One, vol. 6, no. 1, article e15842, 2011.

[109] A. E. Oro and K. Higgins, "Hair cycle regulation of hedgehog signal reception," Developmental Biology, vol. 255, no. 2, pp. 238-248, 2003.

[110] C. S. L. Hoi, S. E. Lee, S. Y. Lu et al., "Runx1 directly promotes proliferation of hair follicle stem cells and epithelial tumor 
formation in mouse skin," Molecular and Cellular Biology, vol. 30 , no. 10 , pp. $2518-2536,2010$.

[111] B. St-Jacques, H. R. Dassule, I. Karavanova et al., "Sonic hedgehog signaling is essential for hair development," Current Biology, vol. 8, no. 19, pp. 1058-1069, 1998.

[112] M. Kadaja, B. E. Keyes, M. Lin et al., "SOX9: a stem cell transcriptional regulator of secreted niche signaling factors," Genes \& Development, vol. 28, no. 4, pp. 328-341, 2014.

[113] K. Foitzik, G. Lindner, S. Mueller-Roever et al., "Control of murine hair follicle regression (catagen) by TGF- $\beta$ lin vivo," FASEB Journal, vol. 14, no. 5, pp. 752-760, 2000.

[114] K. Foitzik, R. Paus, T. Doetschman, and G. Paolo Dotto, “The TGF- $\beta 2$ isoform is both a required and sufficient inducer of murine hair follicle morphogenesis," Developmental Biology, vol. 212, no. 2, pp. 278-289, 1999.

[115] N. Oshimori and E. Fuchs, "Paracrine TGF- $\beta$ signaling counterbalances BMP-mediated repression in hair follicle stem cell activation," Cell Stem Cell, vol. 10, no. 1, pp. 63-75, 2012.

[116] W. Qiu, M. Lei, L. Zhou et al., "Hair follicle stem cell proliferation, Akt and Wnt signaling activation in TPA-induced hair regeneration," Histochemistry and Cell Biology, vol. 147, no. 6, pp. 749-758, 2017.

[117] L. Dong, H. Hao, J. Liu et al., "A conditioned medium of umbilical cord mesenchymal stem cells overexpressing Wnt7a promotes wound repair and regeneration of hair follicles in mice," Stem Cells International, vol. 2017, Article ID 3738071, 13 pages, 2017.

[118] E. Kandyba and K. Kobielak, "Wnt7b is an important intrinsic regulator of hair follicle stem cell homeostasis and hair follicle cycling," Stem Cells, vol. 32, no. 4, pp. 886-901, 2014.

[119] D. Enshell-Seijffers, C. Lindon, M. Kashiwagi, and B. A. Morgan, "Beta-catenin activity in the dermal papilla regulates morphogenesis and regeneration of hair," Developmental Cell, vol. 18, no. 4, pp. 633-642, 2010.

[120] E. Kalabusheva, V. Terskikh, and E. Vorotelyak, "Hair germ model in vitro via human postnatal keratinocyte-dermal papilla interactions: impact of hyaluronic acid," Stem Cells International, vol. 2017, Article ID 9271869, 14 pages, 2017.

[121] R. M. Hoffman, L. Li, and W. Cao, "Hair-shaft growth in Gelfoam $^{\circledR}$ histoculture of skin and isolated hair follicles," Methods in Molecular Biology, vol. 1760, pp. 133-144, 2018.

[122] R. Anderi, N. Makdissy, A. Azar, F. Rizk, and A. Hamade, "Cellular therapy with human autologous adipose-derived adult cells of stromal vascular fraction for alopecia areata," Stem Cell Research \& Therapy, vol. 9, no. 1, p. 141, 2018. 


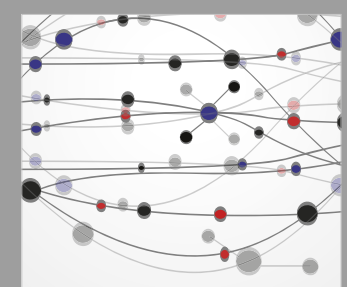

The Scientific World Journal
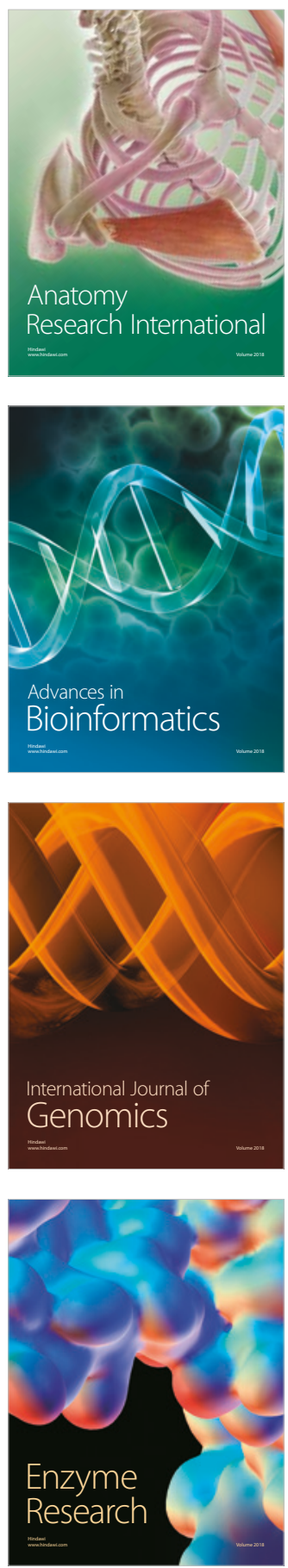


Submit your manuscripts at

www.hindawi.com
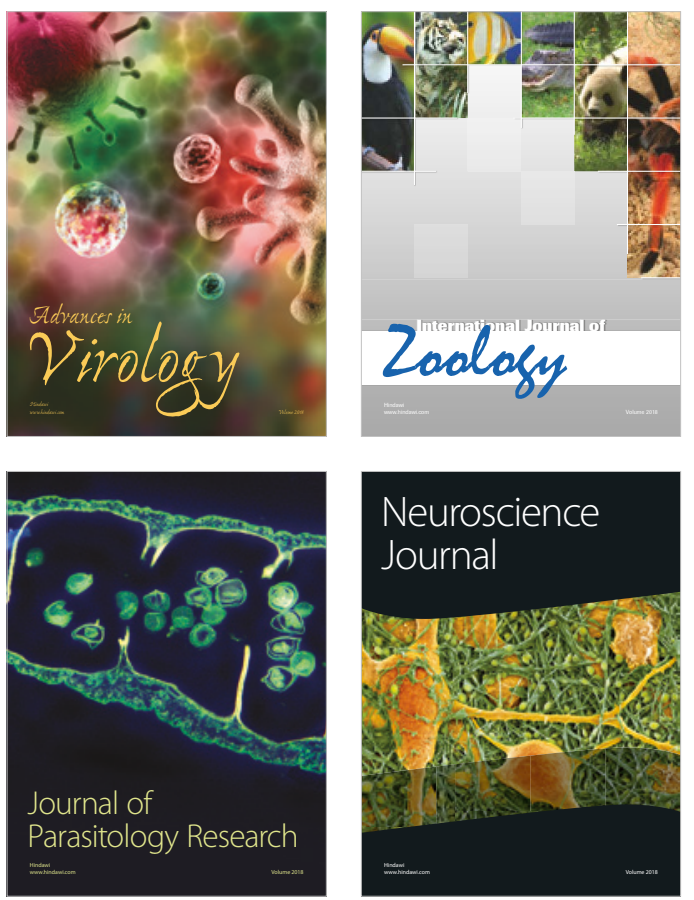
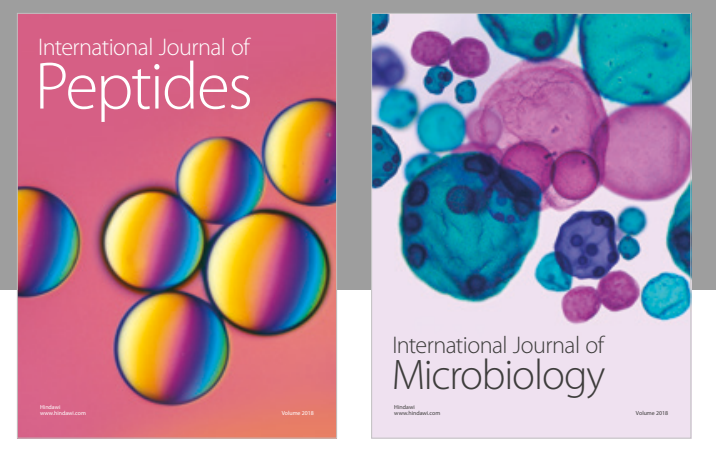

nternational Journal of Microbiology
Journal of
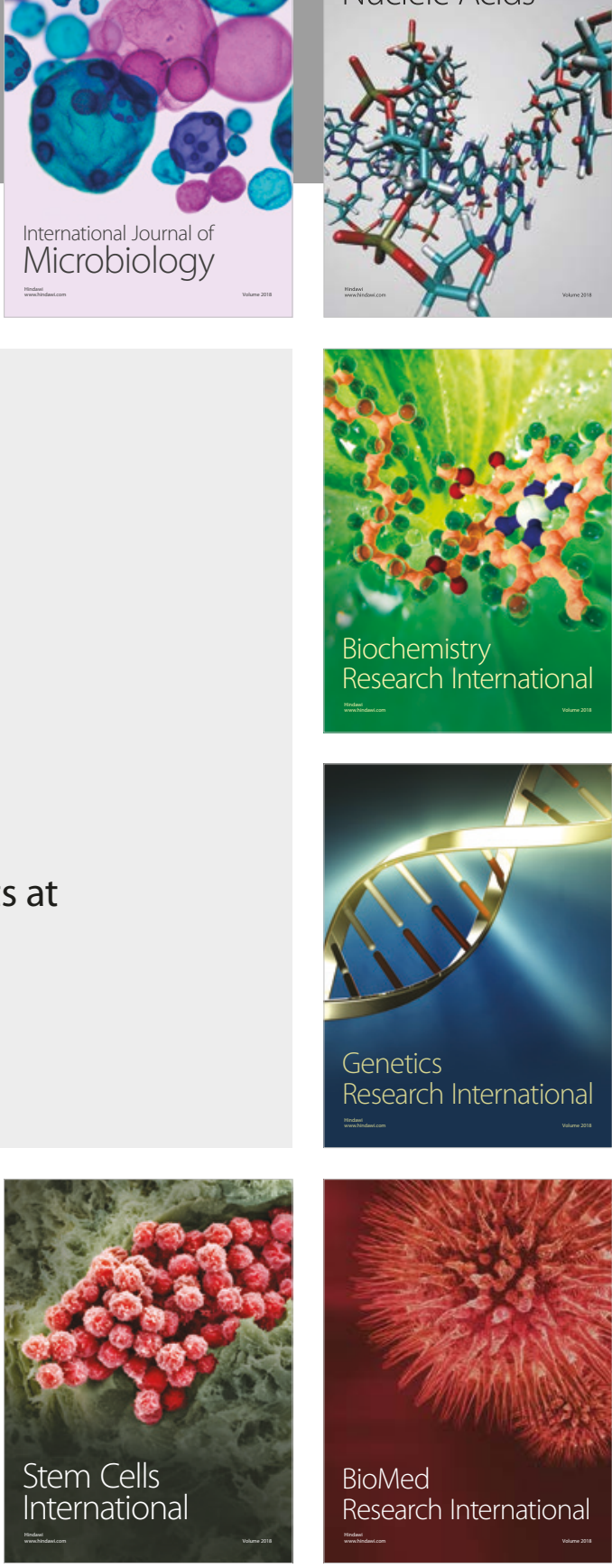
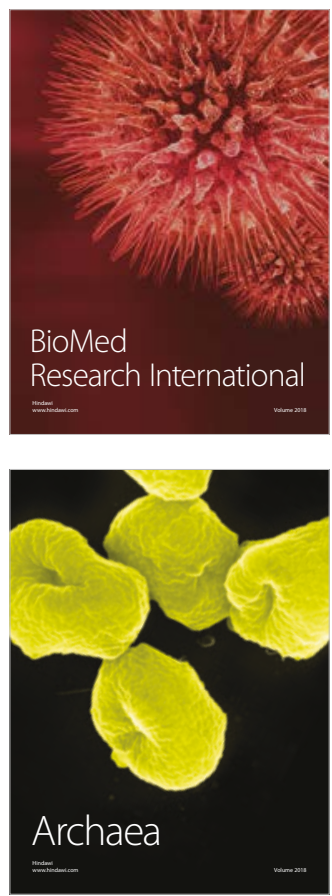